\title{
Geology and Gold Mineralization around Kutcheri, northwestern Nigeria
}

\author{
Amuda, A.K ${ }^{1}$, Danbatta, U.A ${ }^{2}$ and Najime, $T^{3}$ \\ ${ }^{1,2}$ \& 3 Department of Geology, Ahmadu Bello University, Zaria, Nigeria
}

\begin{abstract}
The study area predominantly consists of metasediments, porphyritic granites with minor amphibolite dykes, quartz vein and quartzofeldspathic intrusions. The metasediments are fractured and folded in places. The dominant fold axes and quartz vein intrusions trend NNE-SSW parallel to the regional foliation of the rocks. Artisanal mining of placer gold mineralization were documented around the banks of Rivers in northwestern part of the study area. Panning of 40kg sediments from pits in the area around Gidan Boss and Dutsen Burka yields $0.28 \mathrm{~g}$ Au. Grain morphology shows both eluvial and alluvial deposits occur. The eluvial gold are presumed to occur within steeply dipping $\left(70^{\circ} \mathrm{E}\right.$ and above) quartz veins. Geochemical analysis of 13 quartz vein samples to characterize samples enriched with target $(\mathrm{Au})$ and some pathfinder elements $(\mathrm{Pb}, \mathrm{Hg}$, $\mathrm{Cu}, \mathrm{Ag}$ and $\mathrm{Zn})$ above background levels were carried out. The concentration in ppm had Au (<1-4.8) and others, $\mathrm{Pb}(<1-28), \mathrm{Hg}(<0.5), \mathrm{Cu}(6.2$ to 61.4), $\mathrm{Ag}(<0.5)$ and $\mathrm{Zn}(8.8$ to 39). There is no significant difference between concentration of analytes in Dutsen Burka and Gidan Boss at $\alpha=0.05$. Also, strong positive correlation between $\mathrm{Au}$ and $\mathrm{Cu}, \mathrm{Au}$ and $\mathrm{Pb}$ confirms they are indicator elements for $\mathrm{Au}$ in the area.
\end{abstract}

Keywords: correlation, fold axes, geochemical analysis, pathfinder and target elements, placer gold

\section{Introduction}

The study area is bounded by latitude $11^{\circ} 48^{\prime}$ to $11^{\circ} 53^{\prime} \mathrm{N}$ and longitude $07^{\circ} 00^{\prime}$ to $7^{\circ} 05^{\prime} \mathrm{E}$ and span an area of about $86 \mathrm{~km}^{2}$. It is located in Chafe Local Government area of Zamfara State and falls within the Federal Survey map of Nigeria Sheet 78, Funtua NW (Fig. 1a). It forms part of one (Wonaka Schist Belt) out of twelve Precambrian to Early Paleozoic Schist belts in Nigerian Basement Complex (Fig. 1b).

The schist belts are mainly within the western half of Nigeria and are composed of low-medium grade deformed metasediments and metavolcanics that are intruded by granitoids [1]. Wonaka belt is distinctive in composition and metamorphism [2]. The metasediments are mainly hornfelsic biotite schist [3,4]. The metamorphism is of a higher temperature and lower pressure type than in other schist belts [2].

Gold mineralization is present in alluvial and elluvial placers and primary veins from several parts of supracrustal (schist) belts in the northwest and southwest of Nigeria [5]. Also, most of the NW Nigeria schist belts that have been studied are polymetallic and are endowed with mineralization such as gold $[6,7,8]$, Banded Iron Formation [9,10], marble [10], manganese [12,13] etc associated with them. The Wonaka Schist Belt will probably not be an exception; hence the need for its detailed study.

Gold grain morphology uses the weathering of gold as a means to classify gold grains and narrow down their distance from source. Gold grains are classified into three categories:

a. pristine in which primary shapes and surface textures are preserved

b. modified in which some primary shapes and surface textures are preserved, however, the edges and protrusions have been damaged during transport.and

c. reshaped in which primary textures are destroyed and original grain shape is not discernible [14].

Synthesis of the geological and geochemical characteristics of Phanerozoic mesothermal lode gold deposits with concentration >1ppm are usually associated with $\mathrm{Ag}, \mathrm{Sb}, \mathrm{As}, \mathrm{W}, \mathrm{Hg}, \mathrm{Bi}, \mathrm{Mo}, \mathrm{Pb}, \mathrm{Zn}, \mathrm{Cu}, \mathrm{Ba}$ [15]. Hence, anomalous concentration of the indicator elements is precursors to discriminate presence of gold in an area.

This study have for the first time documented the occurrence of placer gold around Kutcheri. Also, present work aim to discern the geology, structures and gold mineralization to serve as a preliminary exploration guide for gold in the study area. 


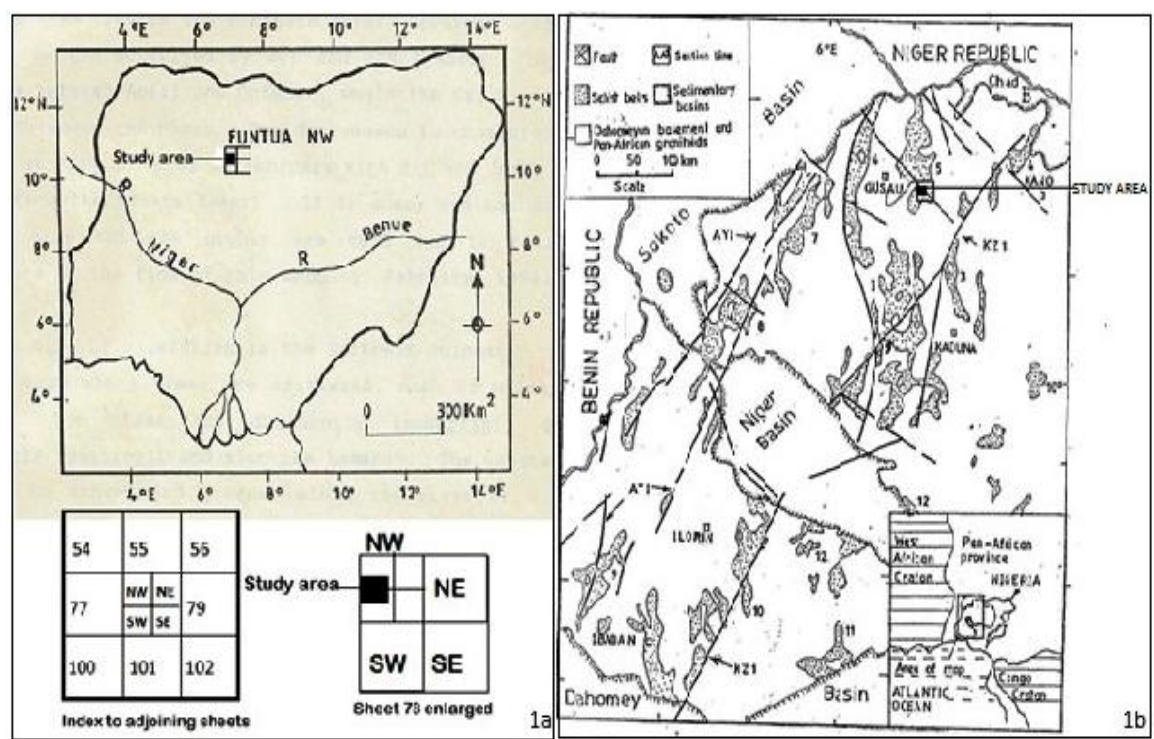

Fig. 1: (a) Map of Nigeria showing location of the study area (not to scale) and (b) Study area within a simplified geological map of the Northern and Southern part of the Western half of Nigeria, showing the distribution of the schist belts and the locations of major lineaments (modified [16] in [17]). The schist belts are 1. Zungeru-Birning Gwari, 2. Kushaka, 3. Malumfashi, 4. Kazaure, 5. Wonaka, 6. Maru, 7. Anka, 8. Zuru, 9. Iseyin-Oyan River, 10. Ife-Ilesha, 11. Igarra-Kabba-Lokoja, 12. Toto, AYI = Anka-Yauri-Iseyin fault system. KZI= Kalangai-Zungeru-Ifewara fault system.

\section{Methodology}

The present research work which was done in five steps. These include:

2.1 Literature Review: that includes relevant published and unpublished work on Nigeria basement Geology and gold mineralization.

2.2 Fieldwork: on scale 1:25,000 that includes two days reconnaissance and seven days detailed field mapping using Compass clinometer-Global Positioning System (GPS) traversing method. The compass clinometer was used to measure trend and dips of lithologies and other structural features on outcrops. A digger and shovel was used to sample about 20kg sediments each from Dutsen Burka and Gidan Boss for panning. Representative samples (rocks) for petrographic studies and geochemical analysis were taken from outcrops with a sledge hammer. Also, a chisel head hammer was used to randomly sample quartz veins lengthwise from south towards the north at about $40 \mathrm{~m}$ interval.

2.3 Map Digitization: Topographic map of the study area were scanned and uploaded into MapInfo software (MapInfo Professional 11.0). It was digitized at scale 1:25,000.

2.4 Laboratory Analysis

2.4.1 Thin section production and petrographic studies: Five thin sections were produced and analyzed with polarized light microscope. Photomicrographs are uploaded into JMicro Vision 1.2.7 software for modal analysis.

2.4.2 Panning and grain morphology: The pan had concentric grooves that help trap denser gold grains by liquefaction upon shaking in water. Diameters of grains are measured with ruler.

2.4.3 Geochemical analysis: Thirteen quartz vein samples were crushed, pulverized, homogenized to $<75 \mu$ and digested (Aqua regia). Appropriate volume of the supernatant solution was taken for elemental analysis using Atomic Absorption Spectrophotometer (AAS) in Multi-User Science Research Laboratory, A.B.U, Zaria.

2.5 Data Interpretation: Descriptive statistics and other tools (t-test, correlation coefficient) in Microsoft excel were used. Also, structural data were plotted with rosette diagram software (Rozeta 2.0).

\subsection{Fieldwork and Petrography}

\section{Results and Discussion}

3.1.1 Field relationships: Biotite schist constitutes about 55\% of rocks in the area. It covers the entire northwestern part, most of the northeastern part and a cone shaped area in contact with porphyritic biotite granite (PBG) in the southwestern part (Fig. 2). Phyllite covers area around Gimba in the northern edge of the northeastern part of the area. It constitutes about 3\% of lithologies in the area (Fig. 2). Porphyritic biotite granite (PBG) constitutes about 32\% of rocks in the area. It mainly covers areas around Kutcheri within southwestern part and most of the southeastern part (Fig 2). The remaining area (about 5\%) is occupied by minor lithologies which include amphibolite dyke, quartz vein (in metasedments) and quartzofeldspathic pegmatites (in PBG). 


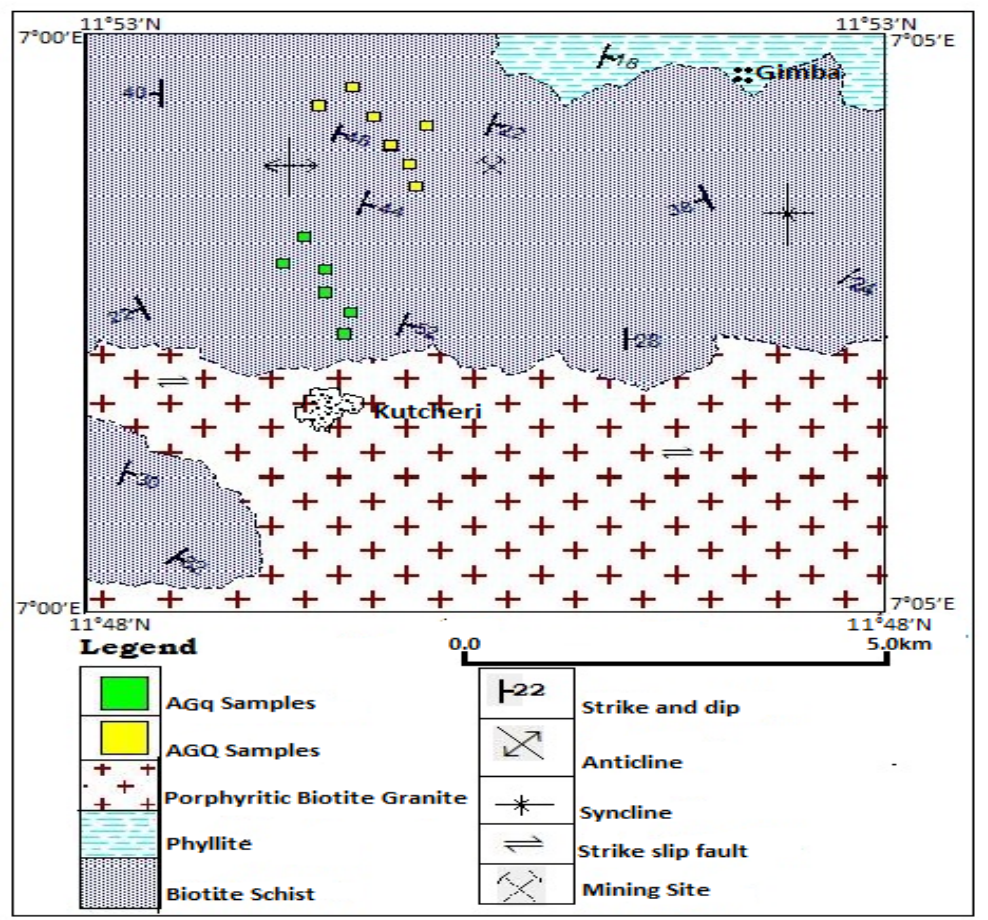

Fig. 2: Geological map of area around Kutcheri.

\subsubsection{Petrographic analysis}

3.1.2.1 Biotite schist: The hand specimens of the biotite schist (BSch) are mostly light brown. Flakes of dark mica, lined up parallel to each other, and separated by light-coloured material, which are mostly millimetrecentimetre sized quartz/feldspar crystals with schistose texture. In few BSch samples, traces of green colour chlorite that resulted from alteration of biotite were noted with the aid of hand lens. The schists are highly weathered in most locations.

In thin section, the samples are relatively equigranular with uniform mineral assemblages of quartz, feldspar (plagioclase), biotite and opaque minerals (Plate I and II). In few exceptions muscovite and pyroxene is present in addition to this assemblage (Table 1).

Table 1: Modal composition of minerals in major lithologies in the study area

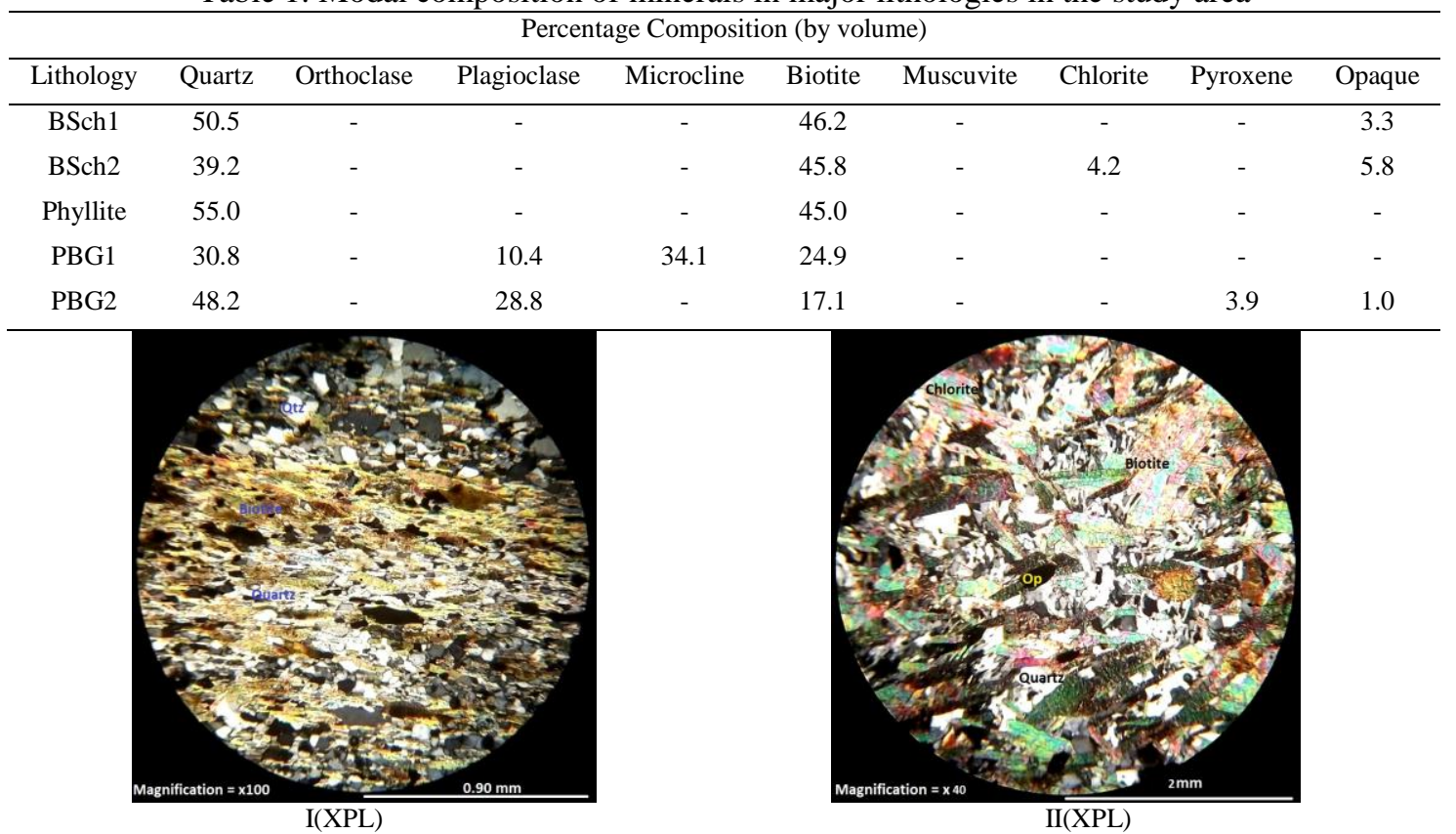

Plate I: Photomicrograph of BSch1 with lepidoblastic foliation pattern with yellow and brown interference colour in biotite Plate II: Photomicrograph of BSch 2 showing biotite with different polarization colours (green, yellow, brown, pink) 
3.1.2.2 Phyllite: The hand specimen appears flattened with tiny platy minerals line up in the same direction, giving the rock a cleavage. It readily split into thin sheets along the cleavage.

In thin section, it is xenoblastic, lepidoblastic with brown to faint yellow biotite that is needle like with wavy slaty texture, high relief and strong pleichroism from light to dark brown (Plate III). It contains nearly same proportion of quartz and biotite by volume (Table 1 ).

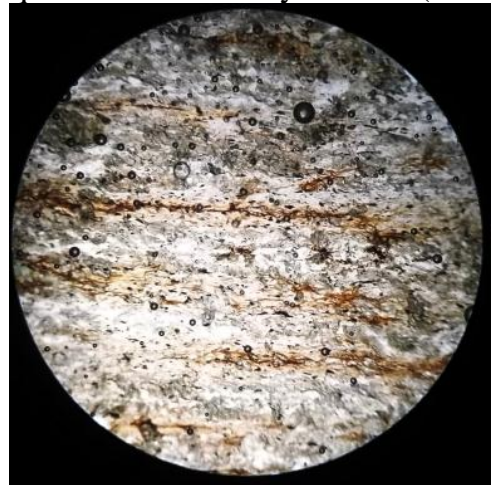

III (PPL)

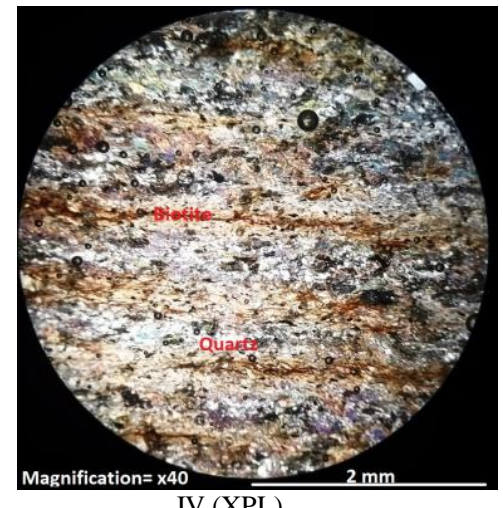

IV (XPL)

Plate III: Photomicrograph of Phyllite with slaty foliation pattern in biotite and quartz.

Plate IV: Photomicrograph of Phyllite showing light brown polarization colour in biotite.

3.1.2.3 Porphyritic biotite granite: The hand specimens are light grey and generally porphyritic with white coloured, foliated phenocryst of feldspars. The texture consists of interlocking crystals up to $2 \mathrm{~cm}$ across. The feldspar phenocrysts show regular blocky shapes.

In thin section (Plate $\mathrm{V}$ and $\mathrm{VI}$ ) the rocks are porphyritic in texture, with phenocrysts of microcline in a groundmass made up of quartz, orthoclase feldspar, plagioclase feldspar and biotite (Table 1).

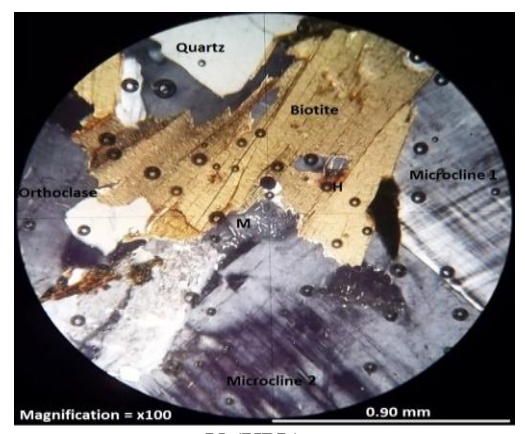

$\mathrm{V}(\mathrm{XPL})$

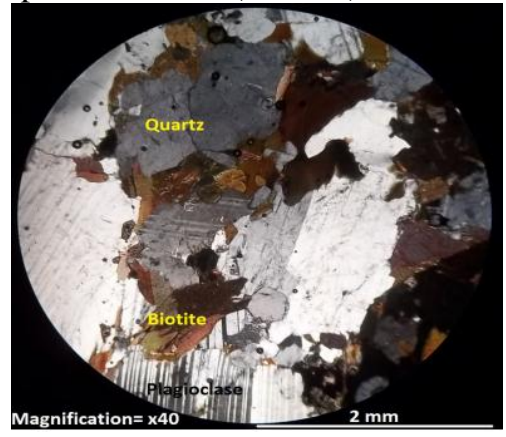

VI (XPL)

Plate V: Photomicrograph of PBG1 showing different tartan twinning pattern in microcline. Myremekitic texture (M) PlateVI: Leucocratic PBG2 showing plagioclase feldspar with characteristic narrow multiple albite twinning pattern

\subsection{Structures}

The metasediments had foliations that mainly trend in NNE-SSW direction (Fig. 3a) with curvilinear joints, folds (macroscale crenulation cleavage pattern, chevron folding, disseminated quartz vein, isoclinal folding, and open folds) and strike slip faults (dextral and sinistral). Also, a number of NW-SE fractures are noted around Gidan Boss (Fig. 3b). Differential stress (tensional stress) in NE-SW direction leads to brittle deformation which account for predominance of joints and faults in NW-SE direction in the area (Fig. 3b). The predominant fault (NW-SE) is perpendicular to the regional Kalagai Fault system [18].

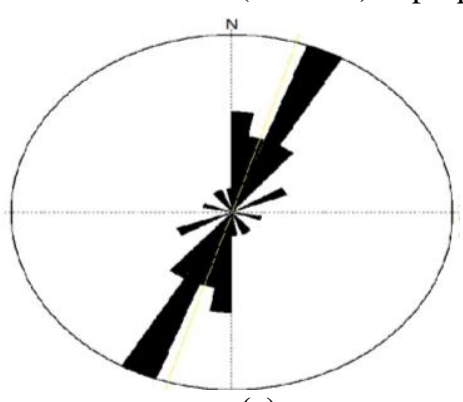

(a)

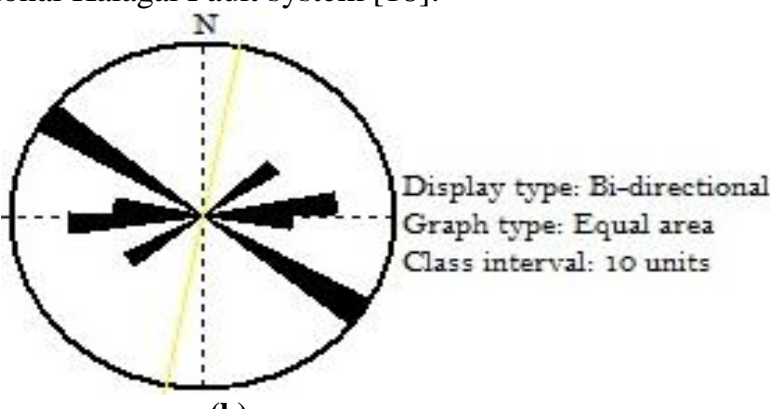

(b)

Fig. 3: (a) Rose diagram showing trend of foliation in metasediments (mica schist and phyllite)

(b) Rose diagram showing joints on metasediments within the study area 


\subsection{Panning and Grain Morphology}

About 20kg each of sediments from pits at Dutsen Burka and Gidan Boss (artisanal mining site) yielded $0.12 \mathrm{~g}$ and $0.16 \mathrm{~g}$ Au respectively. Diameters of grains range from $\leq 4 \mathrm{~mm}$ to $6 \mathrm{~mm}$ (Plate VII and VIII). Based on [14] scheme of classification of grains, the $6 \mathrm{~mm}$ grain had sharp tapering edges (Plate VII) and is thought to be prestine and eluvial while some others had smooth, curved edges and others had tapering edge but flattened (Plate VIII) are thought to be modified and alluvial. Hence, the grains in the sediments are suggested to have resulted from ductile deformation of in-situ (proximal or far) quartz vein.
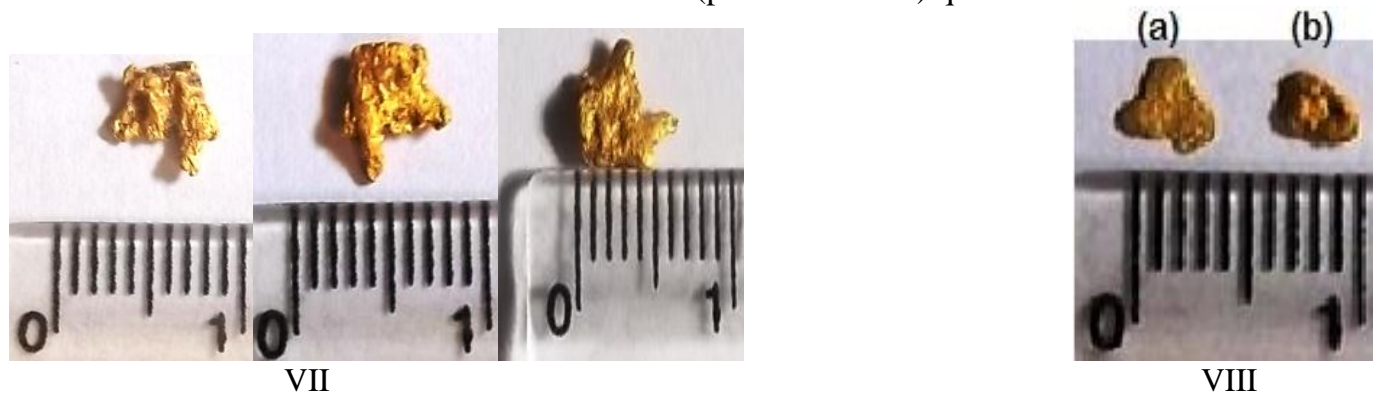

Plate VII: Photograph showing different orientation direction of $6 \mathrm{~mm}$ grain with sharp tapered edges Plate VIII: Photograph of grains with (a) sharp edges but flattened and (b) smooth curved edges

\subsection{Chemical analysis and statistical relation}

\subsubsection{Descriptive statistics and T-test}

The results show concentrations of most analytes are anomalous (Table 2 and 3). Levels of significance of variation in concentration of analytes were compared with two tailed t-test assuming unequal variances (Table 2 and 3). A null hypothesis (Ho) that there is no significant difference in concentrations of target and pathfinder elements around Dutsen Burka and Gidan Boss at $\alpha=0.05$ level of significance was set.

Table 2: Concentration of analytes around Gidan Boss and statistical relations

\begin{tabular}{|c|c|c|c|c|c|c|}
\hline Location & Analyte & & & & & \\
\hline AGQ2 & 4.80 & 0.42 & 61.40 & 28.00 & 39.00 & 0.49 \\
\hline AGQ4 & 2.24 & 0.22 & 8.80 & 10.40 & 4.00 & 0.24 \\
\hline AGQ5 & 1.80 & 0.00 & 7.60 & 10.20 & 0.00 & 0.32 \\
\hline AGQ6 & 0.00 & 0.00 & 7.20 & 0.40 & 12.00 & 0.00 \\
\hline Mean & 1.92 & 0.09 & 22.53 & 11.31 & 0.23 & 12.86 \\
\hline Variance & 2.68 & 0.03 & 458.87 & 95.91 & 0.03 & 199.48 \\
\hline SD & 1.64 & 0.17 & 21.42 & 9.79 & 0.18 & 14.12 \\
\hline t Stat & 2.09 & 0.19 & 1.95 & 2.00 & 0.51 & -0.27 \\
\hline t Critical two tail & 2.31 & 2.23 & 2.44 & 2.31 & 2.20 & 2.23 \\
\hline $\mathrm{P}(\mathrm{T} \leq \mathrm{t})$ two tail & 0.07 & 0.86 & 0.10 & 0.08 & 0.62 & 0.79 \\
\hline
\end{tabular}

Table 3: Concentration of analytes around Dutsen Burka and statistical relations

\begin{tabular}{|c|c|c|c|c|c|c|}
\hline Location & Analyte & & & & & \\
\hline Dutsen Burka & Au & Hg & $\mathbf{C u}$ & $\mathbf{P b}$ & $\mathbf{Z n}$ & Ag \\
\hline AGq8 & 0.60 & 0.00 & 4.80 & 6.40 & 22.00 & 0.42 \\
\hline AGq9 & 0.00 & 0.00 & 6.50 & 0.00 & 8.80 & 0.00 \\
\hline AGq10 & 1.82 & 0.00 & 7.40 & 8.00 & 12.40 & 0.28 \\
\hline AGq11 & 0.00 & 0.00 & 6.40 & 1.20 & 6.00 & 0.00 \\
\hline $\mathrm{AGq} 12$ & 0.00 & 0.00 & 6.20 & 0.00 & 8.60 & 0.17 \\
\hline AGq13 & 0.54 & 0.44 & 8.80 & 4.80 & 30.00 & 0.20 \\
\hline Range & $<0.1-1.8$ & $<0.05-0.44$ & $4.80-8.80$ & $0.03-8.0$ & $6.00-30.00$ & $<0.1-0.42$ \\
\hline Mean & 0.49 & 0.07 & 6.69 & 11.31 & 14.63 & 0.18 \\
\hline Variance & 0.50 & 0.03 & 1.78 & 12.02 & 88.07 & 0.03 \\
\hline SD & 0.71 & 0.18 & 1.33 & 3.47 & 9.38 & 0.16 \\
\hline t Stat & 2.09 & 0.19 & 1.95 & 2.00 & -0.27 & 0.51 \\
\hline t Critical two tail & 2.31 & 2.23 & 2.45 & 2.31 & 2.23 & 2.21 \\
\hline $\mathrm{P}(\mathrm{T} \leq \mathrm{t})$ two tail & 0.07 & 0.86 & 0.10 & 0.08 & 0.79 & 0.62 \\
\hline
\end{tabular}

Generally, the concentration of the target element and pathfinder elements are higher than standard deviation of the mean around Gidan Boss while other samples had their concentration within this range except for quartz vein AGQ6 and AGQ7 which have their concentrations less than standard deviation of the mean for $\mathrm{Au}, \mathrm{Pb}$ and $\mathrm{Ag}$. Also, quartz vein samples around Dutsen Burka generally scatter around the range but had $\mathrm{Au}$ and $\mathrm{Pb}$ 
higher than the threshold for quartz vein AGq10. Also, a similar pattern is noted for quartz vein AGq13 for analytes $\mathrm{Hg}, \mathrm{Cu}$ and $\mathrm{Zn}$.

The $t$ Start value is generally less than the $t$ Critical value for all samples. This means that the $\mathrm{P}$ values are greater than 0.05 for all the analytes. Therefore, there is no significant statistical difference between the analytes. The null hypothesis that there is no significant difference in concentration of analystes around Dutsen Burka and Gidan Boss was accepted.

\subsubsection{Correlation coefficient}

Pearson correlation coefficient show all indicator elements $\mathrm{Hg}, \mathrm{Ag}, \mathrm{Cu}, \mathrm{Zn}$ and $\mathrm{Pb}$ positively correlate with $\mathrm{Au}$ at different levels, $\mathrm{Au} / \mathrm{Hg}(\mathrm{r}=0.48), \mathrm{Au} / \mathrm{Zn}(\mathrm{r}=0.51), \mathrm{Au} / \mathrm{Cu}(\mathrm{r}=0.84), \mathrm{Au} / \mathrm{Pb}(\mathrm{r}=0.97), \mathrm{Au} / \mathrm{Ag}(\mathrm{r}=$ 0.77 ) as shown in Fig. 4.

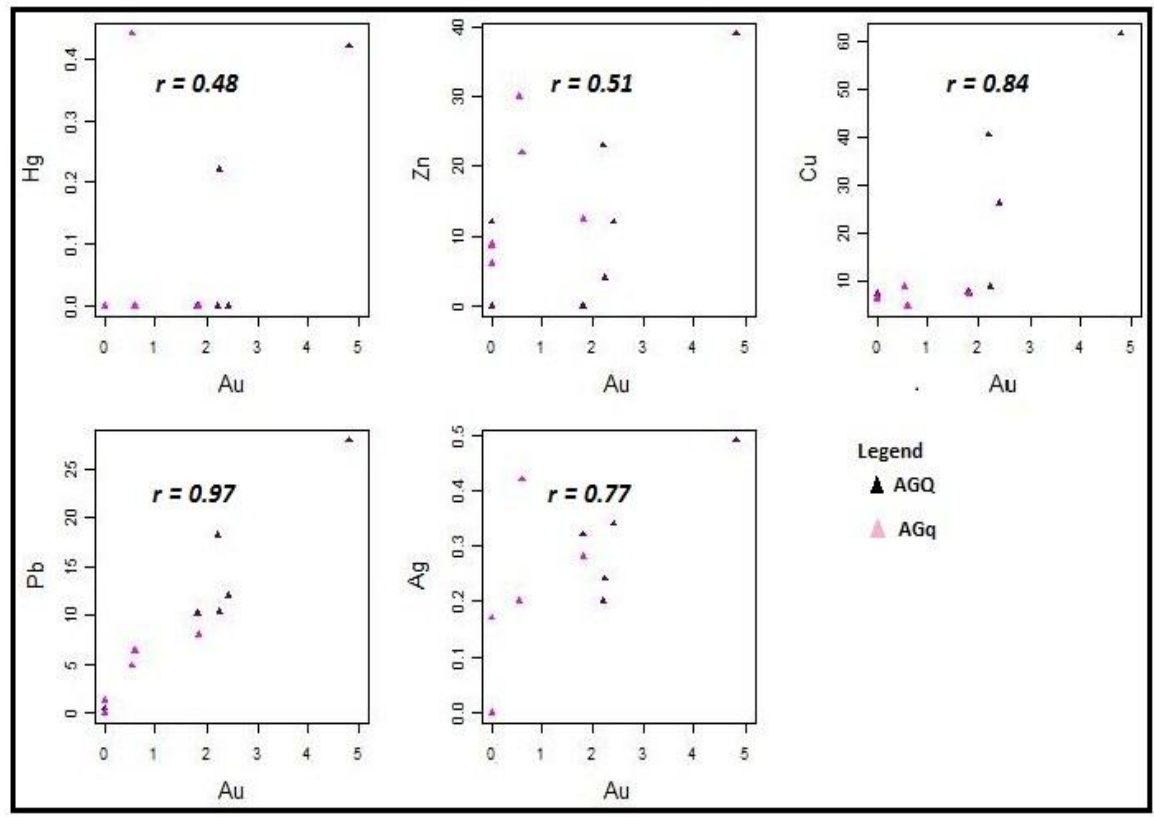

Fig. 4: Bivariate plot of $\mathrm{Au}$ against other trace element $(\mathrm{Hg}, \mathrm{Zn}, \mathrm{Cu}, \mathrm{Pb}$ and $\mathrm{Ag})$

Base metals $\mathrm{Ag}, \mathrm{Pb}$ and $\mathrm{Cu}$ are chemically active while $\mathrm{Au}$ is a noble metal that is chemically inert (under most conditions). Resultant direct proportional relationship between $\mathrm{Au} / \mathrm{Pb},(\mathrm{r}=0.97)$ and $\mathrm{Au} / \mathrm{Cu},(\mathrm{r}=0.84)$ shows that $\mathrm{Cu}$ and $\mathrm{Pb}$ are indicator elements for $\mathrm{Au}$ in the area. Mobile elements $\mathrm{Ni}, \mathrm{Zn}, \mathrm{Pb}, \mathrm{As}$ and $\mathrm{Cu}$ were used to locate buried gold mineralization in Essase Concession, Eastern Region, Ghana [19].

\section{Conclusion}

The dominant lithology in the area includes mica schist, phyllite and porphyritic granite. The metasediments generally display lepidoblastic foliation pattern with similar mineral assemblages.

Structurally, the foliation directions (NNE-SSW) and fold axes trend are parallel to the regional foliation record from Pan-African Orogeny. On the other hand, strike of joints (NW-SE) perpendicular to it.

Gold mineralization around Kutcheri is confirmed to have anomalous concentration in most of quartz vein samples investigated. There is higher concentration of analytes in places at Gidan Boss relative to Dutsen Burka. However, it is not high enough to be considered statistically significant with the present number of samples. With the number of samples analysed, it is not possible to distinguish between mineralization reality and random chance. The correlation coefficient shows $\mathrm{Cu}$ and $\mathrm{Pb}$ are indicator elements for $\mathrm{Au}$ in the area.

\section{Acknowledgements}

The authors thank Village Head Gidan Chido and Kutcheri for accommodating us during field work. Also, we thank staffs Mr. M. Bashir and Mr. E. Silas of Multi-User Science Research Laboratory, A.B.U, Zaria for help in sample pre-treatment and chemical analysis. 


\section{References}

[1]. McCurry, P. (1976). The geology of the Precambrian to Lower Palaeozoic Rocks of Northern Nigeria - A Review. In: Kogbe CA (ed) Geology of Nigeria. Elizabethan Publishers, Lagos, pages 15-39.

[2]. Turner, D.C. (1983). Upper Proterozoic schist belts in the Nigerian sector of the Pan-African Province of West Africa. Precambrian Res 21:55-79.

[3]. McCurry, P. (1971). Pan-African Orogeny in Northern Nigeria. Geological Society of America Bulletine 82: 3251 -3263.

[4]. Harper, C.T., Sherrer, G., McCurry, P. and Wright, J.B. (1973). K-Ar retention ages from the Pan-African of Northern Nigeria. Geological Society of Amererica Bulletine 84, pages 919-926.

[5]. Garba, I. (2003): Geochemical characteristics of mesothermal gold Mineralization in the Pan African (600 \pm 150 ma). Basement of Nigeria. Applied Earth Science, Volume 36 (2), pages 123 - 135.

[6]. Akande, S.O , Fakorede, O. and Mucke, A. (1988). Geology and genesis of gold bearing quartz veins at Bini Yauri and Okolom in the Pan-African domain of western Nigeria. Geologie en Mijnbouw 67. Pages 41-51.

[7]. Garba, I. and Akande, S.O. (1992). Origin and significance of CO2 bearing fluid inclusion in the Bin Yauri gold quartz veins of Northwestern Nigeria. Mineralium Deposita, 27, pages 249-255.

[8]. Garba, I. (2000): Gold prospects of the Nigeria Pan African terrain of West Africa. Journal of Mining and Geology, Vol. 36 (2), pages $123-135$.

[9]. Mucke, A., Annor, A. and Neumann, U. (1996). The Algoma-type iron-formations of Nigerian metavolcano-sedimentary schist belts. Mineralium Deposita 31: 113-122.

[10]. Ibrahim, A.A. (2008). Petrography, geochemistry and origin of banded iron-formation of the Kazaure schist belt, Western Nigeria. Journal of Mining and Geology 44 (1), pages 13-20

[11]. Wright, J.B. (1985). Geology and mineral resources of West Africa. George Allen \& Unwin, London, 187 pages 111-123.

[12]. Mucke, A. (2005). The Nigerian manganese-rich iron-formations and their host rocks - from sedimentation to metamorphism. Journal of African Earth Sciences, 41 (5), pages 407-436.

[13]. Bafor, B.E and Mücke, A. (1990). The genesis of manganese concretions in the Igarra area, Southwestern Nigeria. Journal of African Earth Sciences, 40 (4), pages 307-346).

[14]. DiLabio, R. N. W. (1990). Classification and interpretation of the shapes and surface textures of gold grains from till on the Canadian Shield; Current Research, Part C, Geological Survey of Canada, Paper 90-1C, pages 323-329.

[15]. Nesbitt, B.E. (1991): Phanerozoic gold deposits in tectonically active continental margins. In: Foster, R.P. (ed.), Gold metallogeny and exploration, Blackie and Son, Glasgow and London, pages 104-132

[16]. GSN. (1994). Geological survey of Nigeria map of Nigeria, 1:2,000,000. Geological survey of Nigeria.

[17]. Danbatta, U.A. (2008). Precambrian crustal development in the northwestern part of Zuru schist belt, northwestern Nigeria. Journal of Mining and Geology. 44 (1), pages 45-56

[18]. Garba, I. (2002). Late Pan-African tectonics and origin of gold mineralization and rare-metal pegmatites in the Kushaka schist belt, northwestern Nigeria. Nigerian Journal of Mining and Geology, 38, pages 1-12.

[19]. Amedjoe, C.G and Adjovu, I.T. (2013): Application of the mobile metal ion geochemical technique in the location of buried gold mineralization in Essase Concession, Eastern Region, Ghana. Journal of Geology and Mining Research. Volume 5, Number 6, pages 147-160. 